\title{
SISTEM PENILAIAN INDEKS KINERJA DOSEN MENGGUNAKAN METODE SIMPLE ADDITIVE WEIGHTING
}

\author{
Febryan Ervan ${ }^{1}$, Marsani Asfi ${ }^{2}$, Chandra Lukita ${ }^{3}$ \\ Universitas Catur Insan Cendekia \\ Jl. Kesambi 202 Kota Cirebon, 0231200418/0231 242112 \\ e-mail: febryanervan8@gmail.com¹, marsani.asfi@cic.ac.id², chandra.luktia@cic.ac.id ${ }^{3}$
}

\begin{abstract}
Abstrak
Indikator penilaian kinerja dosen yang dilakukan tiap semester melalui kuesioner dari mahasiswa hanya memiliki satu variabel saja, yaitu mahasiswa. Oleh karena itu diperlukan variabel penilaian lainnya serta metode dalam penilaian kinerja dosen. Penelitian penilaian kinerja dosen ini menggunakan enam variabel yaitu tingkat pendidikan, jabatan fungsional, beban kinerja dosen, kegiatan penelitian, pengabdian kepada masyarakat, dan hasil kuesioner mahasiswa. Metode Simple Additive Weighting (SAW) menggunakan penjumlahan terbobot dalam mencari rating kinerja setiap alternatif semua atribut. Tahapan penelitiannya yaitu pengelolaan data enam variabel yang berupa data vektor, selanjutnya penentuan alternatif, penentuan kriteria, pemberian Nilai Rating Kecocokan, penentuan Bobot Preferensi, kemudian dibuat Tabel Rating Kecocokannya. Hasil dari matrik keputusan digunakan untuk menghitung Nilai Rating Kinerja ternormalisasi dalam bentuk matrik, dan Nilai Preferensi yang dihasilkan dijadikan penentuan Indeks Kinerja(IKD) dosen. Hasil penelitian ini berupa aplikasi berbasis web penentuan Indeks Kinerja Dosen (IKD) yang merupakan implementasi dari tahapan SAW, serta menghasilkan penilaian yang bersifat objektif.
\end{abstract}

Kata kunci: Indeks, Kinerja, Dosen, Preferensi, Simple Additive Weigthing

\begin{abstract}
Indicators of lecturer performance conducted every semester through questionnaires from students only have one variable. Therefore we need other assessment variables and methods in evaluating lecturer performance. This lecturer performance appraisal study uses six variables, namely education level, functional position, lecturer performance burden, research activities, community service, and student questionnaire results. Simple Additive Weighting (SAW) method uses the weighted sum in finding the performance rating of each alternative for all attributes. The stages of the research are the management of six variable data in the form of vector data, then the determination of alternatives, determination of criteria, giving a Match Rating Value, determining Weight Preferences, then making a Match Rating Table. The results of the decision matrix are used to calculate the Normalized Performance Rating Value in the form of a matrix, and the resulting Preference Value is used as a determination of the lecturer Performance Index (IKD). The results of this study are in a web-based application to determine Lecturer Performance Index (IKD) which is an implementation of the SAW stage, and produces an objective assessment.
\end{abstract}

Keywords: indeks, performance, lecture, Simple Additive Weighting, preference 


\section{PENDAHULUAN}

Secara umum proses penilaian kinerja dosen hanya menggunakan satu variabel penilaian yaitu kuesioner yang diisi oleh mahasiswa melalui google form. Data penilaian kuesioner diolah menggunakan microsoft excel yang menghasilkan penilaian dalam bentuk Indeks Kinerja Dosen (IKD). Penilaian kuesioner masih dipengaruhi unsur subjektifitas dan memerlukan waktu yang cukup lama untuk menganalisanya, sehingga diperlukan lebih dari satu variabel penilaian untuk menghilangkan unsur subjektifitas. Oleh kerena itu diperlukan sistem pendukung keputusan untuk membantu proses penilaian Indeks Kinerja Dosen (IKD). Dokumen sistem dalam penelitian ini bersumber dari dokumen penilaian indeks kinerja dosen di Universitas Catur Insan Cendekia (UCIC). Diharapkan dengan adanya sistem pendukung keputusan ini bisa menghasilkan penilaian yang objektif dan mempercepat waktu penilaian. Sistem penilaian ini berguna bagi Biro Pengendalian Mutu serta dapat menjadi model bagi perguruan tinggi lainnya dalam pengambilan keputusan baik ditingkat program studi, fakultas maupun institusi.

Prestasi kerja atau kinerja adalah catatan tentang hasil-hasil yang diperoleh dari fungsi-fungsi pekerjaan tertentu atau kegiatan selama kurun waktu tertentu. Penilaian kinerja (performance appraisal) adalah proses mengevaluasi seberapa baik karyawan melakukan pekerjaan mereka jika dibandingkan dengan seperangkat standar, dan kemudian mengkomunikasikan informasi tersebut pada karyawan. [3]

Penelitian terkait, yaitu seleksi dosen berprestasi di STMIK CIC Cirebon menggunakan metode AHP. Kriteria yang digunakan adalah Kuesioner Dosen, Meeting Attendance, Penelitian dan Pengabdian Masyarakat, serta Exam Score Submission [2]. Dalam penelitian ini kriteria yang digunakan dalam menentukan Indeks Kinerja Dosen (IKD) adalah Tingkat Pendidikan (TP), Jabatan Fungsional (JF), Beban Kerja Dosen (BKD), sedangkan untuk Kegiatan Penelitian (KP), Pengabdian kepada Masyarakat (PkM) dan Hasil Kuesioner (HK) dari mahasiswa diambil dengan mengacu pada penelitian [2].

Metode Simple Additive Weighting (SAW) membutuhkan proses normalisasi matrik keputusan $(X)$ ke suatu skala yang dapat diperbandingkan dengan semua ranting alternatif yang ada. Metode SAW mengenal adanya 2 (dua) atribut yaitu kriteria keuntungan (benefit) dan kriteria biaya (cost)[1]. Perbedaan mendasar dari kedua kriteria ini adalah dalam pemilihan kriteria ketika mengambil keputusan.[4].

Dalam penelitian ini dengan melakukan revisi kriteria pada [2], maka Penelitian penilaian kinerja dosen ini menggunakan enam variabel yaitu tingkat pendidikan, jabatan fungsional, beban kinerja dosen, kegiatan penelitian, pengabdian kepada masyarakat, dan hasil kuesioner mahasiswa. Penggunaan metode SAW digunakan untuk menyesuaikan dengan kondisi dilapangan.

\section{METODE PENELITIAN}

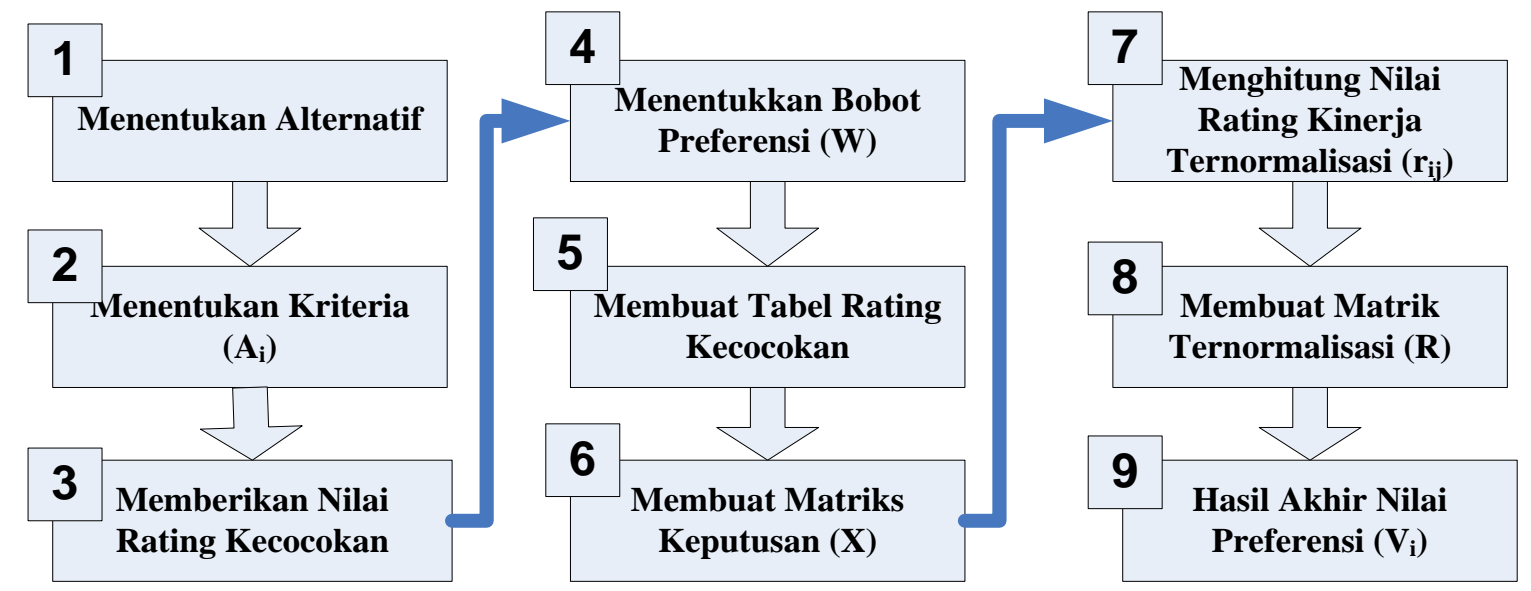

Gambar 1. Tahapan dalam perhitungan IKD menggunakan metode SAW

\subsection{Menentukan Alternatif.}

Data alternatif merupakan data-data utama dosen yang berisi data-data untuk 6(enam) kriteria yang digunakan untuk penilaian kinerja dosen. 


\subsection{Menentukan Kriteria $\left(\mathbf{A}_{\mathbf{i}}\right)$}

Ditahapan ini kriteria dan bobot kriteria yang telah dibuat. Besaran bobot mengacu pada penilaian internal yang dilakukan oleh Biro Penjaminan Mutu(BPM) Universitas CIC. Besaran bobot juga dijadikan standar mutu dalam penentuan indeks kinerja dosen.

Tabel 1. Kriteria dan Bobot Penilaian[2] (dengan revisi)

\begin{tabular}{cclcc}
\hline No & Kriteria & \multicolumn{1}{c}{ Keterangan } & Atribut & Bobot (W) \\
\hline 1. & C1 & Tingkat Pendidikan (TP) & Benefit & $10 \%(0,1)$ \\
\hline 2. & C2 & Jabatan Fungsional (JF) & Benefit & $10 \%(0,1)$ \\
\hline 3. & C3 & Beban Kerja Dosen (BKD) & Benefit & $20 \%(0,2)$ \\
\hline 4. & C4 & Kegiatan Penelitian (KP) & Benefit & $20 \%(0,2)$ \\
\hline 5. & C5 & Pengabdian kepada Masyarakat (PkM) & Benefit & $20 \%(0,2)$ \\
\hline 6. & C6 & Hasil Kuesioner (HK) & Benefit & $20 \%(0,2)$ \\
\hline \multicolumn{5}{c}{ Total } \\
\hline \multicolumn{5}{c}{}
\end{tabular}

\subsection{Memberikan Nilai Rating Kecocokan}

Tabel 3 menjelaskan aturan nilai rating kecocokan setiap alternatif pada setiap kriteria.

Tabel 2. Nilai Rating Kecocokan

\begin{tabular}{cc} 
Nilai & Keterangan \\
\hline 5 & Sangat Baik \\
\hline 4 & Baik \\
\hline 3 & Cukup \\
\hline
\end{tabular}

\subsection{Menentukan Bobot Preferensi (W)}

Menentukan bobot preferensi atau tingkat kepentingan untuk setiap kriteria. Adapun ketentuan bobot kriteria sebagai berikut :

$$
W=\{0,1 ; 0,1 ; 0,2 ; 0,2 ; 0,2 ; 0,2\}
$$

Tabel 3 merupakan data simulasi yang akan digunakan dalam contoh perhitungan. Tabel 3 juga berisi data-data awal yang berisi alternatif, Nilai C1,C2,C3,C4,C5 dan C6.

Tabel 3. Data Awal

\begin{tabular}{l|c|c|c|c|c|c}
\multirow{2}{*}{$\begin{array}{c}\text { Alternatif } \\
\text { (Nama Dosen) }\end{array}$} & \multicolumn{6}{|c}{ Kriteria } \\
\cline { 2 - 7 } & TP $(\mathbf{C 1})$ & $\begin{array}{c}\text { JF } \\
(\mathbf{C 2})\end{array}$ & $\begin{array}{c}\text { BKD } \\
(\mathbf{C 3})\end{array}$ & $\begin{array}{c}\text { KP } \\
(\mathbf{C 4})\end{array}$ & $\begin{array}{c}\text { PkM } \\
(\mathbf{C 5})\end{array}$ & $\begin{array}{c}\text { HK } \\
\text { (C6) }\end{array}$ \\
\hline A1 & S2 & LK & 11 & 2 & 1 & $>$ RRK \\
\hline A2 & S3 & L & 13 & 3 & 0 & $=$ RRK \\
\hline A3 & S3 & AA & 12 & 4 & 2 & $>$ RRK \\
\hline A4 & S2 & L & 12 & 2 & 2 & $=$ RRK \\
\hline A5 & S3 & LK & 10 & 3 & 2 & $>$ RRK
\end{tabular}

\subsection{Membuat Tabel Rating Kecocokan}

Tabel 3 selanjutnya diubah menjadi tabel rating kecocokan seperti tabel 4 yang menjelaskan data data awal atau data kualitatif yang dirubah ke dalam data kuantitatif. Nilai kuantitatif menyesuaikan dengan nilai rating kecocokan yang telah ditentukan diawal tahapan 2.3.

Tabel 4. Rating Kecocokan

\begin{tabular}{|c|c|c|c|c|c|c|}
\hline \multirow[b]{2}{*}{ Alternatif } & \multicolumn{6}{|c|}{ Kriteria } \\
\hline & TP (C1) & $\begin{array}{c}\mathbf{J F} \\
(\mathrm{C} 2)\end{array}$ & $\begin{array}{l}\text { BKD } \\
\text { (C3) }\end{array}$ & $\begin{array}{c}\text { KP } \\
\text { (C4) }\end{array}$ & $\begin{array}{l}\text { PkM } \\
\text { (C5) }\end{array}$ & $\begin{array}{l}\text { HK } \\
\text { (C6) }\end{array}$ \\
\hline A1 & 4 & 5 & 3 & 4 & 4 & 5 \\
\hline A2 & 5 & 4 & 5 & 5 & 3 & 4 \\
\hline A3 & 5 & 3 & 4 & 5 & 5 & 5 \\
\hline A4 & 4 & 4 & 3 & 4 & 5 & 4 \\
\hline A5 & 5 & 5 & 4 & 5 & 5 & 5 \\
\hline
\end{tabular}




\subsection{Membuat Matriks Keputusan (X)}

Tabel 5. Merrupakan data yang digunakan sama dengan data rating kecocokan hanya bedanya ditambahkan dengan nilai maksimum dari setiap alternatif karena kriteria yang digunakan merupakan atribut benefit atau keuntungan.

Tabel 5. Matrik Keputusan

\begin{tabular}{c|c|c|c|c|c|c}
\multirow{2}{*}{$\mathbf{A}_{\mathbf{i}}$} & \multicolumn{7}{|c}{$\mathbf{C}_{\mathbf{j}}$} \\
\cline { 2 - 7 } & $\mathbf{C 1}$ & $\mathbf{C 2}$ & $\mathbf{C 3}$ & $\mathbf{C 4}$ & $\mathbf{C 5}$ & $\mathbf{C 6}$ \\
\hline $\mathrm{A} 1$ & 4 & 5 & 3 & 4 & 4 & 5 \\
\hline $\mathrm{A} 2$ & 5 & 4 & 5 & 5 & 3 & 4 \\
\hline $\mathrm{A} 3$ & 5 & 3 & 4 & 5 & 5 & 5 \\
\hline $\mathrm{A} 4$ & 4 & 4 & 3 & 4 & 5 & 4 \\
\hline $\mathrm{A} 5$ & 5 & 5 & 4 & 5 & 5 & 5 \\
\hline Nilai Max & $\mathbf{5}$ & $\mathbf{5}$ & $\mathbf{5}$ & $\mathbf{5}$ & $\mathbf{5}$ & $\mathbf{5}$
\end{tabular}

\subsection{Menghitung Nilai Rating Kinerja Ternormalisasi}

Tahapan berikutnya adalah menghitung nilai rating kinerja ternormalisasi untuk masing-masing alternatif dengan data yang bersesuaian dengan kriteria yang bersesuaian. Contoh perhitungannya seperti perhitungan (1.1 dan 1.2) :

Normalisasi Matriks A1 dan A4 :

$\mathrm{R} 11=\frac{4}{\operatorname{Max}\{4,5,5,4,5\}}=\frac{4}{5}=0,8$
$\mathrm{R} 41=\frac{4}{\operatorname{Max}\{4,5,5,4,5\}}=\frac{4}{5}=0,8$

Dimana nilai 4 adalah nilai untuk kriteria $\mathrm{C} 1$ pada alternatif $\mathrm{A} 1$, sedangkan $\operatorname{Max}(4,5,5,4,5)$ adalah nilai maksimum yang akan dicarikan dalam kreiteria $\mathrm{C} 1$ yang ada.

\subsection{Membuat Matrik Ternormalisasi (R)}

Ditahapan ini hasil dari perhitungan normalisasi setiap kriteria yang membentuk matriks ternormalisasi dan angka yang berada di dalam tabel matrik ternormalisasi merupakan hasil pembulatan. Tabel 6 merupakan contoh matrik ternormalisasi.

Tabel 6. Matrik Ternormalisasi

\begin{tabular}{c|c|c|c|c|c|c}
\multicolumn{1}{c|}{ Bobot $(\mathbf{W})$} & $\mathbf{0 , 1}$ & $\mathbf{0 , 1}$ & $\mathbf{0 , 2}$ & $\mathbf{0 , 2}$ & $\mathbf{0 , 2}$ & $\mathbf{0 , 2}$ \\
\hline \multicolumn{1}{c}{ Atribut } & Benefit & Benefit & Benefit & Benefit & Benefit & Benefit \\
\hline Alaternatif & $\mathbf{C 1}$ & $\mathbf{C 2}$ & $\mathbf{C 3}$ & $\mathbf{C 4}$ & $\mathbf{C 5}$ & $\mathbf{C 6}$ \\
\hline A1 & 0,8 & 1,0 & 0,6 & 0,8 & 0,8 & 1,0 \\
\hline A2 & 1,0 & 0,8 & 1,0 & 1,0 & 0,6 & 0,8 \\
\hline A3 & 1,0 & 0,6 & 0,8 & 1,0 & 1,0 & 1,0 \\
\hline A4 & 0,8 & 0,8 & 0,6 & 0,8 & 1,0 & 0,8 \\
\hline A5 & 1,0 & 1,0 & 0,8 & 1,0 & 1,0 & 1,0
\end{tabular}

\subsection{Hasil Akhir Nilai Preferensi $\left(V_{i}\right)$}

Hasil yang diperoleh dari setiap kriteria yang ternormalisasi (R), langkah selanjutnya yaitu menentukan hasi akhir nilai preferensi $\left(\mathrm{V}_{\mathrm{i}}\right)$ yang diperoleh dari penjumlahan dan perkalian nilai ternormalisasi (R) dengan nilai bobot (W). Hasil perhitungan berikut (2.1 dan 2.2.) :

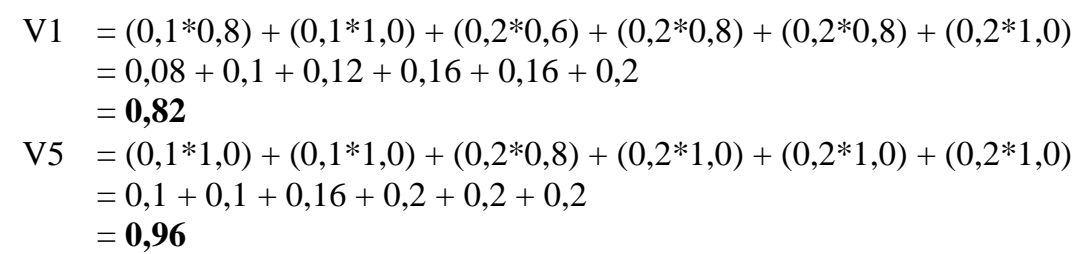

Tabel 7 merupakan hasil akhir contoh perhitungan IKD 


\begin{tabular}{l|c|c|c|c|c|c|c|c}
\multicolumn{1}{c}{ Tabel 7. Preferensi atau Vektor $\left(\mathbf{V}_{\mathbf{i}}\right)$} \\
Alternatif & C1 & C2 & C3 & C4 & C5 & C6 & TOTAL & RANK \\
\hline A1 & 0,08 & 0,1 & 0,12 & 0,16 & 0,16 & 0,2 & $\mathbf{0 , 8 2}$ & $\mathbf{4}$ \\
\hline A2 & 0,1 & 0,08 & 0,2 & 0,2 & 0,12 & 0,16 & $\mathbf{0 , 8 6}$ & $\mathbf{3}$ \\
\hline A3 & 0,1 & 0,06 & 0,16 & 0,2 & 0,2 & 0,2 & $\mathbf{0 , 9 2}$ & $\mathbf{2}$ \\
\hline A4 & 0,08 & 0,08 & 0,12 & 0,16 & 0,2 & 0,16 & $\mathbf{0 , 8 0}$ & $\mathbf{5}$ \\
\hline A5 & 0,1 & 0,1 & 0,16 & 0,2 & 0,2 & 0,2 & $\mathbf{0 , 9 6}$ & $\mathbf{1}$
\end{tabular}

\section{HASIL DAN PEMBAHASAN}

Hasil analisa sistem menggunakan Unified Modelling Language (UML) pada sistem pendukung keputusan untuk menentukan Indeks Kinerja Dosen (IKD).

\subsection{Diagram Use Case System}

Diagram 1, merupakan diagram use case system yang digunakan dalam perancangan sistem penilaian IKD

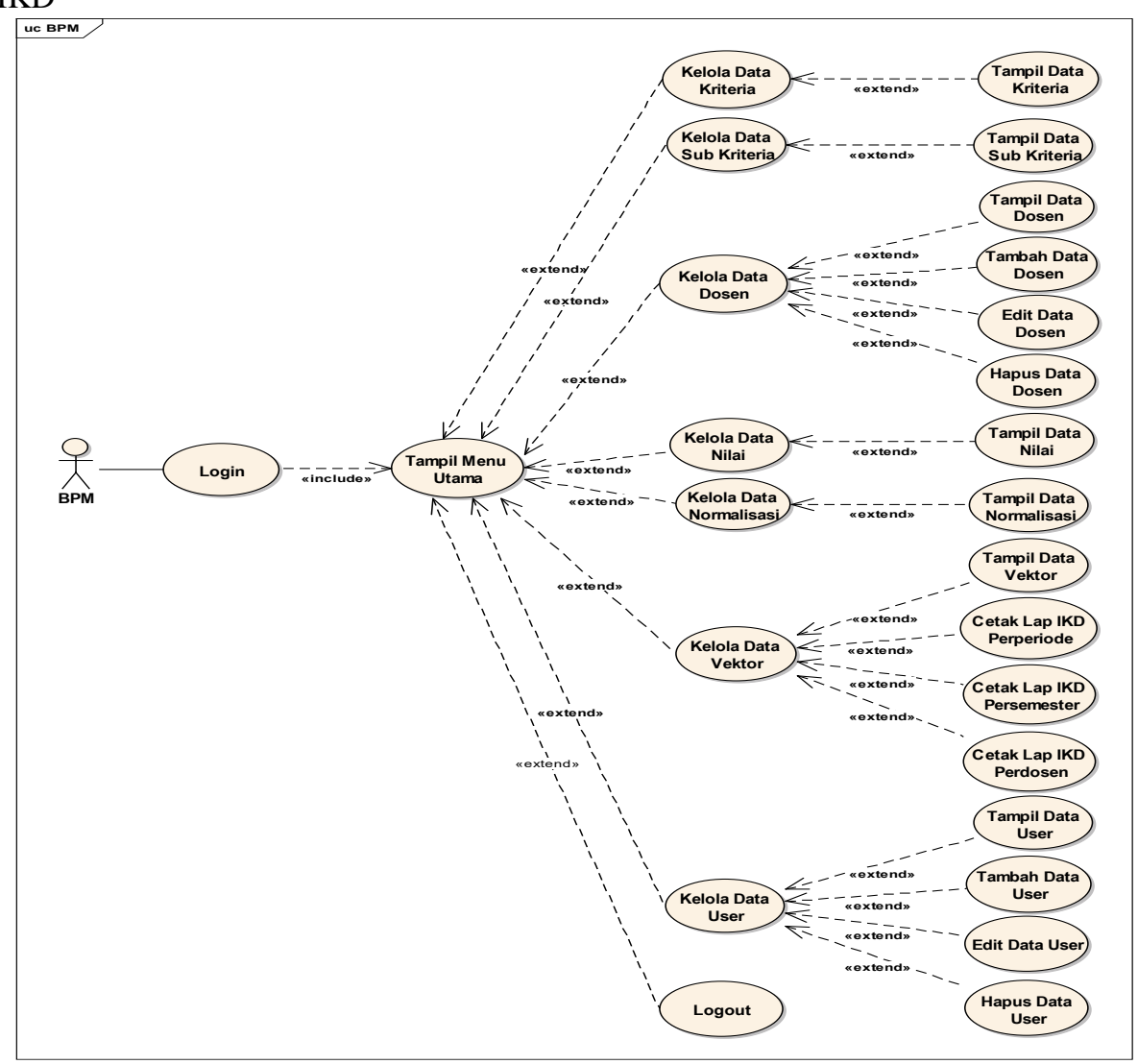

Diagram 1. Use Case Sistem

\subsection{Diagram Activity System}

Diagram activity 2 sistem berisi tahapan sistem yang diusulkan. Tahapan dari login awal, penentuan data-data awal, proses penentuan IKD sampai dengan laporan. Bagian-bagian utama dari diagram activity mencakup kelola data kriteria, kelola data sub kriteria, kelola data dosen, kelola data nilai, kelola data normalisasi, kelola data vektor dan kelola data user. 


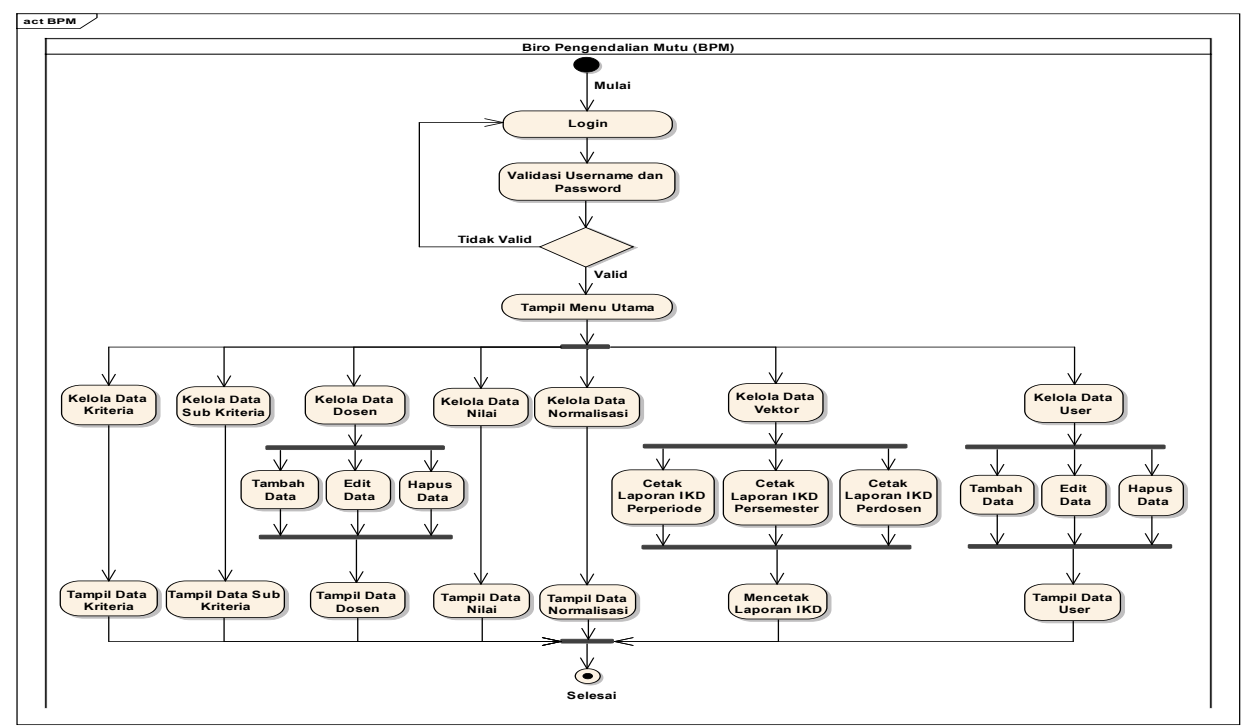

Diagram 2. Diagram Activity Sistem

\subsection{Diagram Sequence Sistem}

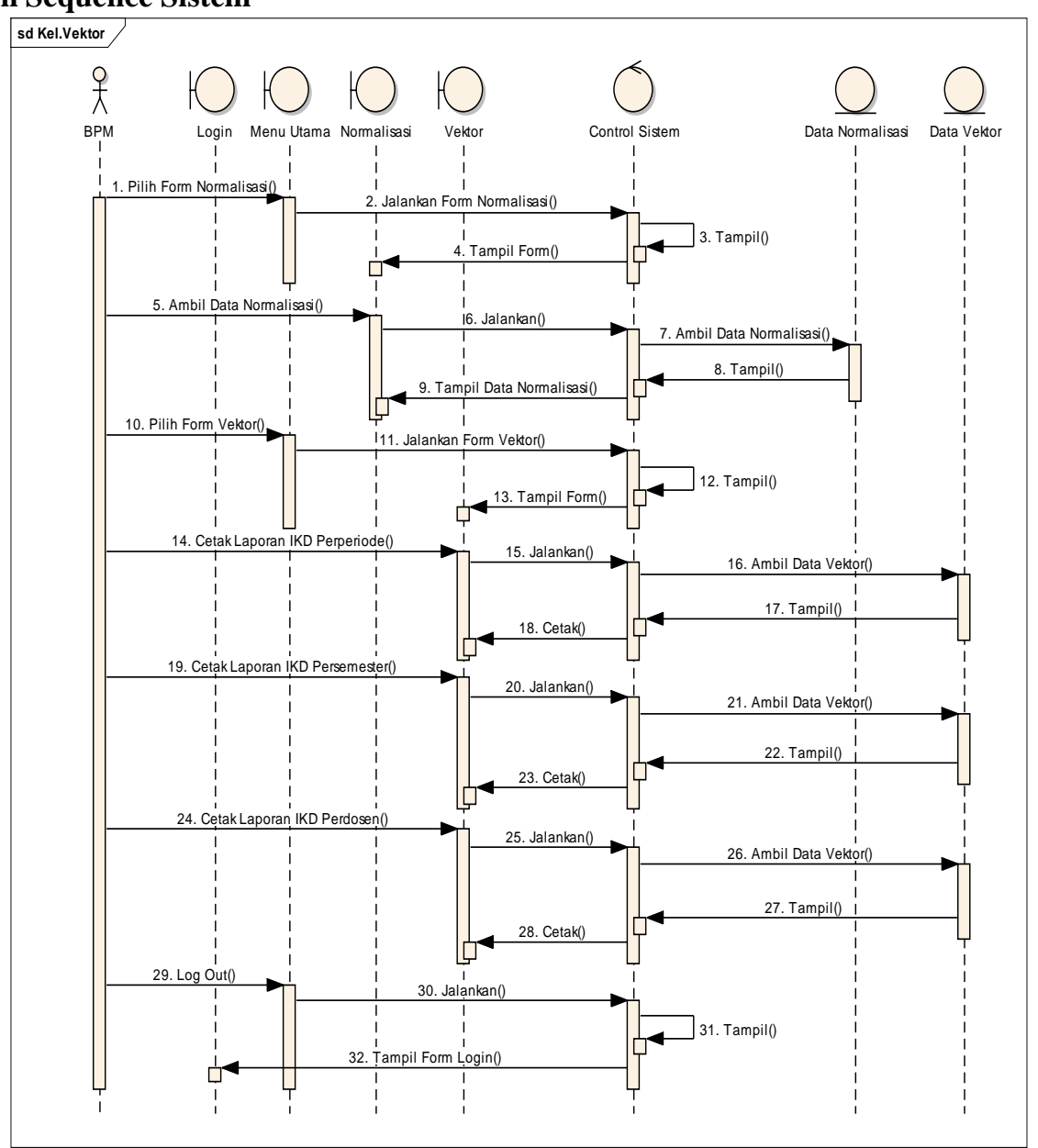

Diagram 3. Diagram Sequence Sistem IKD

Diagram 3, merupakan diagram sequence yang berisi tahapan proses dan keterkaitan antar proses dari sistem penilaian IKD. Terlihat pada diagram 3, proses perubahan tahapan data vektor dan data normalisasi. 


\subsection{Implementasi Sistem}

Implementasi Sistem berupa aplikasi berbasis web yang mencakup

1. Pembuatan kriteria dan sub kriteria beserta bobot penilaian.

2. Mengelola tingkat pendidikan, jabatan fungsional, beban kerja dosen, kegiatan penelitian, pengabdian kepada masyarakat dan data hasil kuesioner.

3. Melakukan perhitungan penilaian indeks kinerja dosen dan mencetak laporan Indeks Kinerja Dosen (IKD)

4. Mengelola data user atau pengguna aplikasi.

5. Mencetak laporan Indeks Kinerja Dosen (IKD) perdosen.

Gambar 3, merupakan form data dosen yang berisi daftar data dosen. Data-data dosen mencakup nidn, nama dosen, periode nilai, semester, tingkat pendidikan, jabatan fungsional, beban kerja dosen, kegiatan penelitian, pengabdian kepada masyarakat, dan hasil kuesioner.

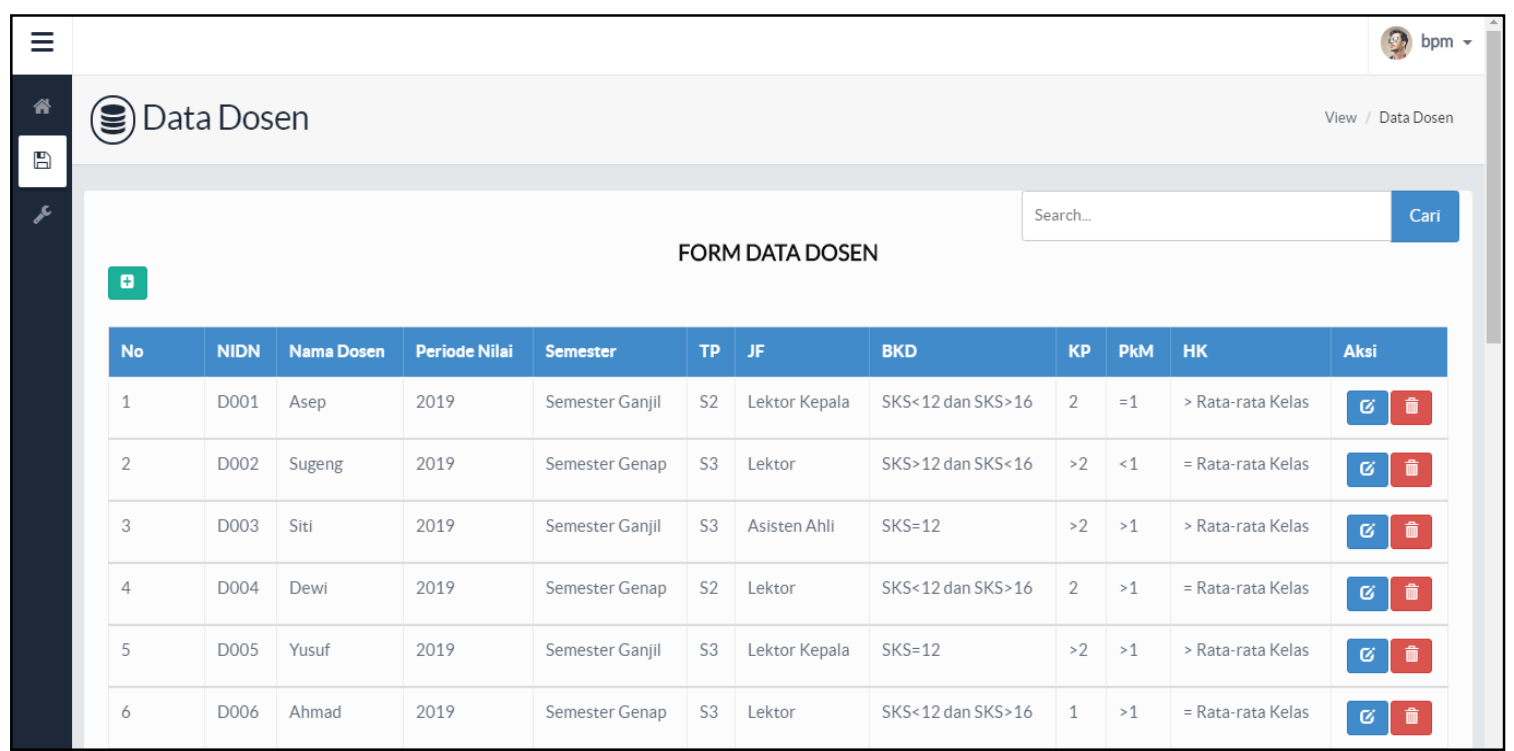

Gambar 2. Implementasi Form data dosen

Sedangkan untuk gambar 3 merupakan implementasi dari form Data nilai. Form ini berisi daftar nilai dari masing-masing kriteria untuk proses menentukan Indeks Kinerja Dosen (IKD). Pada data nilai terdapat id nilai, nidn, nama dosen, periode nilai, semester, tingkat pendidikan, jabatan fungsional, beban kerja dosen, kegiatan penelitian, pengabdian kepada masyarakat, dan hasil kuesioner. 


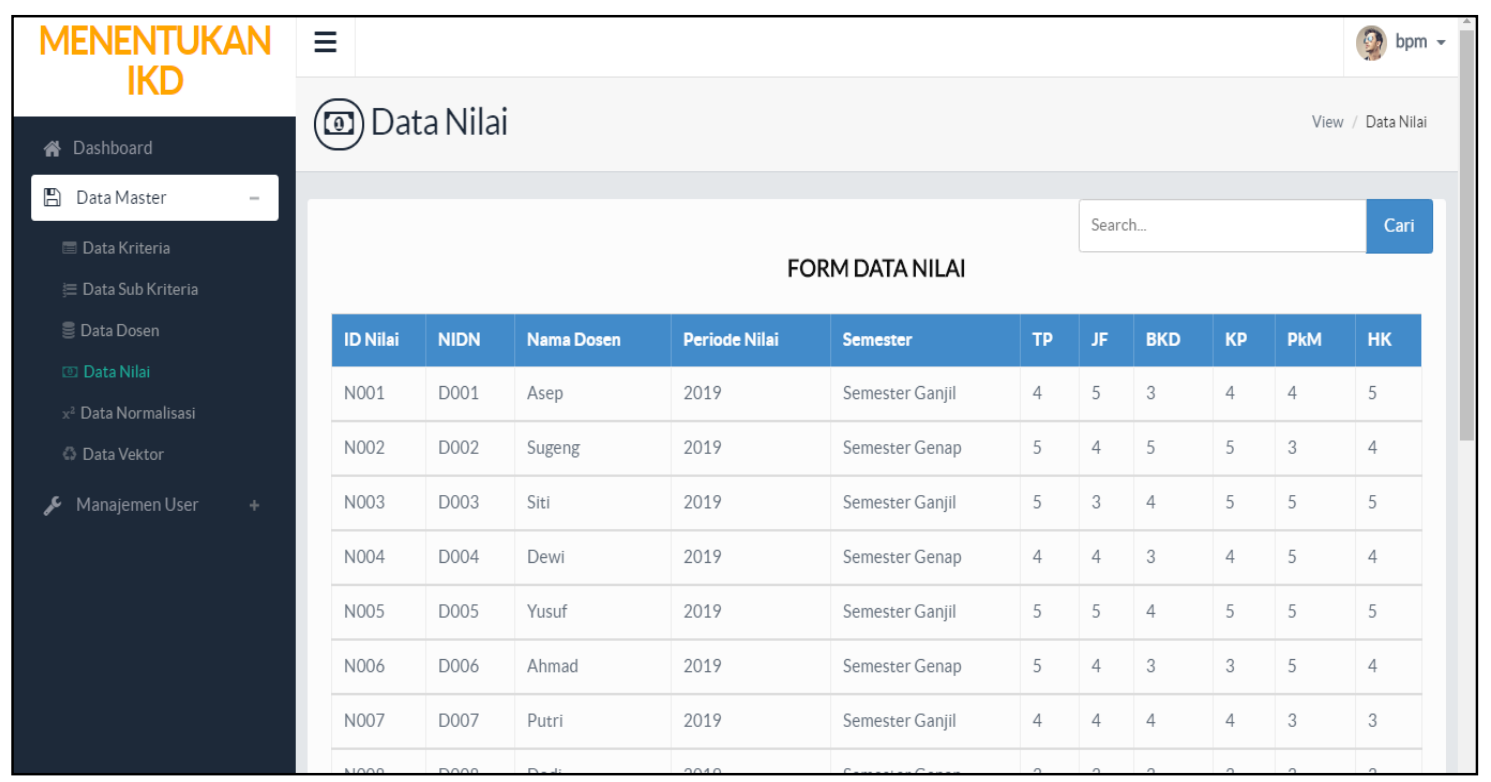

Gambar 3. Implementasi Form Data Nilai

Gambar 4. merupakan implementasi form hasil pengolahan data vektor. Data vektor merupakan hasil akhir dari proses menentukan Indeks Kinerja Dosen (IKD). Pada data normalisasi terdapat id vektor, nidn, nama dosen, periode nilai, semester, tingkat pendidikan, jabatan fungsional, beban kerja dosen, kegiatan penelitian, pengabdian kepada masyarakat, hasil kuesioner, total nilai, index kinerja dosen, dan ranking. Pada data vektor terdapat button cetak yang berfungsi untuk mencetak laporan Indeks Kinerja Dosen.

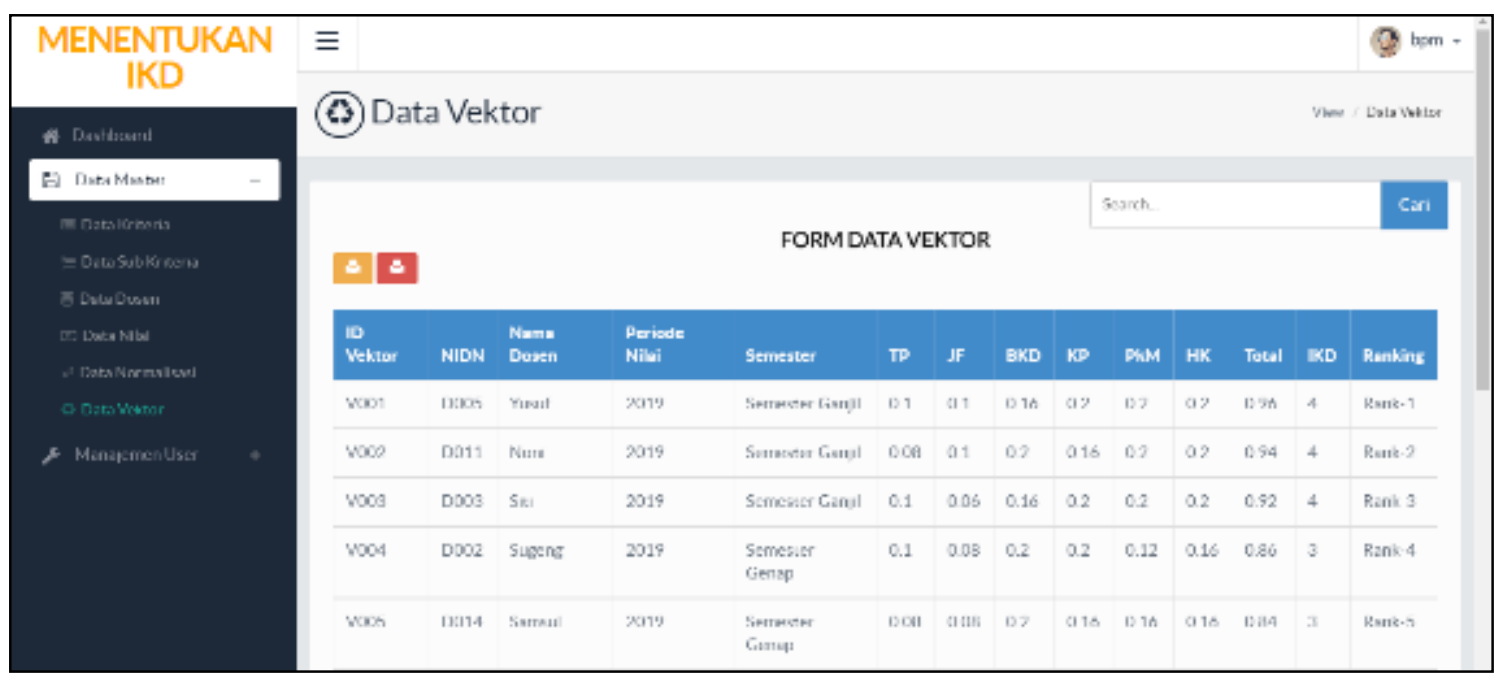

Gambar 4. Form Data Vektor

Gambar 5 merupakan laporan Indeks Kinerja Dosen (IKD) Persemester merupakan hasil dari tabel vektor yang dicetak berdasarkan semester yang dipilih. 


\begin{tabular}{|c|c|c|c|c|c|c|c|c|c|c|c|c|c|}
\hline & & & $\begin{array}{r}\text { LAPO } \\
\text { Semest }\end{array}$ & $\begin{array}{l}\text { N INDEKS K } \\
\text { Ganjil - Taht }\end{array}$ & VER] & A D & ik 20 & N & & & & & \\
\hline ID & NIDN & $\begin{array}{l}\text { Nama } \\
\text { Dosen }\end{array}$ & Periode Nilai & Semester & TP & JF & BKD & $\mathbf{K P}$ & PkM & HK & Total & IKD & Ranking \\
\hline vo01 & D001 & $A \operatorname{sen}$ & 2019 & Semester Ganjlll & 0.08 & \begin{tabular}{|l|}
0.1 \\
\end{tabular} & \begin{tabular}{|l|l}
0,12 \\
\end{tabular} & \begin{tabular}{|l|l|}
0.16 \\
\end{tabular} & 0.16 & 0.2 & 0.82 & 3 & Rank-1 \\
\hline vo02 & D003 & Siti & 2019 & Semester Gunjil & 0.1 & 0.06 & 0.16 & \begin{tabular}{|l|}
0.2 \\
\end{tabular} & 0.2 & 0.2 & 0.92 & 4 & Rank-2 \\
\hline vo03 & D005 & Yusuf & 2019 & Semester Ganjil & 0.1 & \begin{tabular}{|l|}
0.1 \\
\end{tabular} & 0.16 & 0.2 & 0.2 & 0.2 & 0.96 & 4 & Rank-3 \\
\hline Vo04 & D007 & Putri & 2019 & Semester Ganjil & 0.00 & 0.08 & \begin{tabular}{|l|l|}
0.16 \\
\end{tabular} & 0.16 & \begin{tabular}{|l|}
0.12 \\
\end{tabular} & 0.12 & 0.72 & 2 & Rank-4 \\
\hline vo05 & Doog & Foby & 2019 & Semester GanjuI & 0.08 & 0.06 & 0.12 & 0.12 & 0.12 & 0.12 & 0.62 & 2 & Rank-5 \\
\hline V006 & D011 & Noni & 2019 & Semester Ganjuli & 0.08 & 0.1 & \begin{tabular}{|l|}
0.2 \\
\end{tabular} & 0.16 & \begin{tabular}{|l|}
0.2 \\
\end{tabular} & \begin{tabular}{|l|}
0.2 \\
\end{tabular} & 0.94 & 4 & Rank-6 \\
\hline v007 & D013 & Yuki & 2019 & Semester Genjill & 0.1 & \begin{tabular}{|l|}
0.1 \\
\end{tabular} & \begin{tabular}{|l|}
0.16 \\
\end{tabular} & 0.12 & \begin{tabular}{|l|l|}
0.12 \\
\end{tabular} & 0.16 & 0.76 & 2 & Rank-7 \\
\hline voos & D015 & Sandra & 2019 & Semester Ganjil & 0.1 & 0.08 & 0.16 & 0.16 & 0.12 & 0.2 & 0.82 & 3 & Rank-8 \\
\hline & & & & & & & & & & tats-rn & ta IKD & 3 & \\
\hline
\end{tabular}

\section{Gambar 5. Implementasi Output sistem IKD}

Gambar 7 merupakan laporan Indeks Kinerja Dosen (IKD) Perdosen merupakan hasil dari tabel vektor yang dicetak berdasarkan nidn dan semester yang dipilih, seperti pada gambar 6. Pilihan mencetak terdiri dari combo box pilih nidn, pilih semester, dan tombol cetak data perdosen.

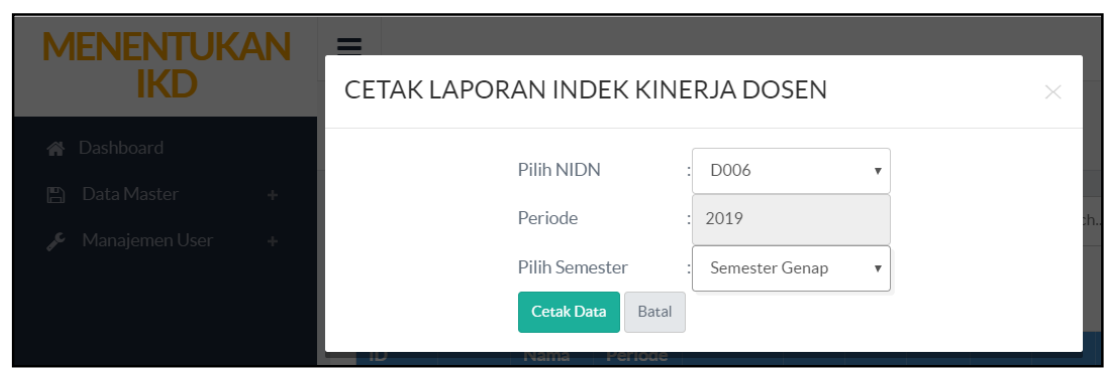

Gambar 6. Implementasi Cetak Laporan IKD per semester

\begin{tabular}{|c|c|c|c|c|}
\hline \multicolumn{5}{|c|}{$\begin{array}{c}\text { LAPORAN INDEKS KINERJA DOSEN } \\
\text { Semester Genap - Tahun Akademik } 2019\end{array}$} \\
\hline \multicolumn{5}{|c|}{ Kepada yth, } \\
\hline Nama Dosen & \multicolumn{4}{|l|}{ : Ahmad } \\
\hline \multicolumn{5}{|c|}{ NIDN $\quad$ : D006 } \\
\hline \multicolumn{5}{|c|}{$\begin{array}{l}\text { Bersama dengan ini Biro Pengendalian Mutu menyampaikan data-data berupa nilai kinerja } \\
\text { Bapak/Ibu dosen untuk Semester Genap tahun akademik 2019, sebagai berikut : }\end{array}$} \\
\hline No & Unsur Penilaian & Keterangan & Nilai & Skor Nilai \\
\hline 1 & Tingkat Pendidikan (TP) & S3 & 5 & 0.1 \\
\hline 2 & Jabatan Fungsional (JF) & Lektor & 4 & 0.08 \\
\hline 3 & Beban Kerja Dosen (BKD) & SKS $<12$ dan SKS $>16$ & 3 & 0.12 \\
\hline 4 & Kegiatan Penelitian (KP) & 1 & 3 & 0.12 \\
\hline 5 & Pengabdian kepada Masyarakat (PkM) & $>1$ & 5 & 0.2 \\
\hline 6 & Hasil Kuesioner (HK) & $=$ Rata-rata Kelas & 4 & 0.16 \\
\hline \multicolumn{4}{|c|}{ Total Nilai } & 0.78 \\
\hline \multicolumn{4}{|c|}{ Nilai IKD } & 2 \\
\hline
\end{tabular}

Gambar 7. Laporan IKD persemester 


\section{KESIMPULAN}

Berdasarkan uraian dari pembahasan mengenai sistem pendukung keputusan untuk menentukan Indeks Kinerja Dosen (IKD) menggunakan metode Simple Additive Weighting (SAW), maka beberapa kesimpulan sebagai berikut :

1. Aplikasi ini memiliki 6 (enam) variabel penilaian yaitu : tingkat pendidikan, jabatan fungsional, beban kerja dosen, kegiatan penelitian, pengabdian kepada masyarakat, dan hasil kuesioner.

2. Aplikasi ini membantu melakukan penilaian terhadap indeks kinerja dosen dan meningkatkan unsur objektifitas terhadap Indeks Kinerja Dosen (IKD) karena menggunakan lebih dari satu variabel penilaian.

3. Aplikasi ini dapat mempercepat penentuan Indeks Kinerja Dosen (IKD) dan menghasilkan perankingan berdasarkan hasil perhitungan menggunakan metode Simple Additive Weighting (SAW).

\section{DAFTAR PUSTAKA}

[1] Kusrini. Konsep Dan Aplikasi Sistem Pendukung Keputusan. Yogyakarta: Andi Offset. 2007.

[2] Marsani A, Chandra L, Amroni A. Sistem Penunjang Keputusan Seleksi Dosen Berprestasi Menggunakan Metode Analytical Hierarchy Process (AHP) di STMIK CIC Cirebon. Proceeding Konferensi Nasional Sistem Informasi 2013 STMIK Bumigora.2013: 14-16.

[3] Mathis, Robert, John J. Manajemen Sumber Daya Manusia. Jakarta : Salemba Empat. 2006: Edisi 10.

[4] Nugraha, F., Surarso, B., \& Noranita, B. Sistem Pendukung Keputusan Evaluasi Pemilihan Pemenang Pengadaan Aset dengan Metode Simple Additive Weighting (SAW). Jurnal Sistem Informasi Bisnis. 2012: 2(2), 2502-2377.

[5] Lukita C, Nas C, Ilham W. Analisis Perbandingan Metode MOORA dan Metode WASPAS Dalam Pendukung Keputusan Penentuan Prioritas Utama Peningkatan Kualitas Mata Pelajaran. Jurnal Nasional Teknologi dan Sistem Informasi. 2019; 5(3): 130-137. ISSN 2476-8812 